\title{
Expenditure Challenges in Underwhelming Countries with Special Reference to UAE
}

\author{
Mohammed Reda Mestareehih
}

\begin{abstract}
The purpose of this investigation is to understand challenges faced by underwhelming countries in executing proper ways to fully benefit from the governmental expenditures. A brief understanding of public expenditure has been given in comparison to the developed countries. The sectors which have been taken into account by the UAE government for channelizing the public expenditure have been detailed and the findings have been used to analyse the reasons for the lack of economic growth in most of the underwhelming countries and proper suggestions have been brought forth to avoid misjudgement while allocating public expenditure.
\end{abstract}

Keywords: Public expenditure, budget, gross domestic product, capital expenditure, revenue expenditure.

Abbreviations: Gross Domestic Product (GDP), United Arab Emirates (UAE).

\section{INTRODUCTION}

The governments of every country spend a huge sum on infrastructure, education, provision, medicine etc... The application of public expenditure didn't gain much importance until the nineteenth century but since the nineteenth century many ways of handling public expenditure have been reinforced in most of the underwhelming countries. The management of public expenditure is a very important task to all the governments but the tasks and procedures applied in managing the public expenditure are quite challenging and hence there is a need to understand the methods and ways applied in executing public expenditure. In most of the developing countries, it is very difficult to manage the public expenditure due to various reasons. Some of the reasons could be lack of resources, inadequate information and the need to spend more than what is available. The budget is also rather different in underwhelming countries when compared to developed countries. The management and maintenance of fiscal discipline to bring out efficient budgeting seems to be quite difficult in underwhelming countries and hence the methods and procedures applied by developed countries are usually different from underwhelming countries. The fundamental principle of economic growth of the country purely depends on its public expenditure.

The investigations of Moreno-Dodson (2008) ${ }^{[1]}$ regarding the impact of government expenditure and the factors associated with economic growth in some underwhelming countries understood that some factors of public expenditure can help us in understanding economic growth though there are minor differences in the methods of government expenditure in each country. Growing problems regarding population, unemployment and poverty cannot be dealt with unless there is a proper distribution of Public expenditure. The allocation of public expenditure for infrastructure, local as well as foreign investments, health and education services and for strengthening the agricultural sector is a great challenge in underwhelming countries as the governments of these countries are unable to prioritise the distribution of public expenditure which eventually leads to budget deficit. Despite the fact that execution of public expenditure in the right way is challenging, UAE has made its mark in proving that the right way of managing public expenditure can make the nation prosperous. With the tremendous growth in different sectors, economic standards of UAE have been on the rise for the last ten years and hence it can be set as a very good example for the underwhelming countries to sustain economic growth.

\section{REVIEW OF LITERATURE}

According to Keynesian macroeconomic theory, positive economic growth is directly proportional to public expenditure and increased government consumption could lead to a decrease in unemployment. On the other hand some economists like Barro and Sala-i-Martin (1992) ${ }^{[2]}$ oppose the Keynesian 
macroeconomic theory as extreme government consumption for economic growth can hamper the private investors' interests resulting in unproductive and unexpected impact of the economic growth rate. Despite these theories, if the government is focused on spending more on basic requirements such as proper amenities to people, building projects for electricity production and maintaining import and export costs to the minimum can facilitate better results while reducing the negative impact on economic growth. Spending more on improving the quality of labour can be fruitful as it generates proper income to the common man as well as the government that will eventually be a positive sign for the economic growth of any underwhelming country. Other economists are of the view that formal education plays an important role and hence the governments should be focused on spending more to develop the public education and the amenities required for educational growth in order to be fruitful.

There have been many researches that prove that money spent on social services can improve the human capability. Blankenau and Simpson (2004) ${ }^{[3]}$ have proved through their models that money spent on the process of human formation has greatly influenced economic growth in a positive way. Since most of the poor people are unable to handle huge medical expenses, it is advised that majority of the expenditure should be in a medical sector because health of the people is the only wealth of any nation. C. Lowell Harris says, "Expenditures have received far less economic analysis. Doubtless more concern about expenditures will develop in the future." ${ }^{[4]}$ Since there is some negativity in political fragmentation when it is associated with public expenditure, it is very important that the expenditures should be economically analysed before being allocated because in most of the countries though proper expenditure methods have been implemented, the results have not been satisfying. Levine and Renelt (1992) ${ }^{[5]}$ have also agreed that there can be a difference when the components of government spending are taken into consideration. As Griffin and McKinley (1992) said, "Human development seldom is served by reducing public expenditure, but it often could be served by altering the composition of public expenditure." [6]

\section{DISCUSSING UAE'S GOVERNMENT EXPENDITURE}

According to the data available from regarding the government spending is the UAE from 2006 to $2016^{[7]}$; the public expenditure has tremendously increased. The impact of this government expenditure can be witnessed positively in the economic growth as well because it has eventually met the social services needed by the people. The GDP of UAE regarding the public expenditure on education for the last ten years has been taken to new heights and that shows that the priority of the government expenditure has been channelized in a proper way. There has also been a tremendous growth in the manufacturing sectors of furniture, construction materials, real estate etc... which again this proves that though managing public expenditure is intriguing yet it can be achieved if the public expenditure is utilised in the right way. Like every other nation, public expenditure for eradication of poverty, human development and public health have been prioritised by the UAE government but the prioritising of these public expenditures has been unique.

Capital expenditure and revenue expenditure are the major two kinds of expenditures that are usually carried out by the governments. The social, economic and general service of the government along with expenditure of central and state falls under the revenue expenditure category. The expenditures incurred by governments for the creation and progress of physical and financial assets fall under the capital expenditure category. UAE has been well balanced in distributing the public expenditure evenly for both revenue as well as capital expenditure. The market forces and political factors also play a very important role in the allocation of public expenditure but UAE has sustained to justify in all directions for its economic growth. The increase in public expenditure resulted in increased output. Public spending on all GDP components has constantly been increasing which proves that UAE has been successful in the application of proper public expenditure methods. This strategy of proper usage of public expenditure has resulted in greater foreign investments in UAE. The size of the UAE GDP has constantly been on the rise and is further expected to increase. All this was possible because UAE focused its public expenditure in various sectors rather than completely relying on oil which is its major source of economy.

\section{FINDINGS}

When it comes to underwhelming countries there is an increase in public expenditure because of the decline in value of money, budget preparation methods, increasing population and internal political disputes. The other general reasons that also affect the public expenditure are political, financial, 
economic, social and military reasons. The reason behind UAE government's success is not because UAE is focused on increasing social capital or productive capital through public expenditure but it is focused on performance of public works that include electricity, water maintenance and providing adequate salaries that help in raising the living standards while helping the country to realise the importance of trade, gas, electricity, industrial and water sector which eventually resulted in great economic growth.

The underwhelming countries have been spending a lot to stabilise their economy but lack of efficiency and effectiveness in managing resources, failing to provide quality education, failure in implementing schemes, unstable institutional and political reforms and failing to understand the importance of gender equality in political representation can be considered as some of the major setbacks which have been challenging. If the underwhelming countries are able to understand and recognise the way UAE has succeeded in channelizing the public expenditure, great economic changes can be witnessed sooner than expected.

\section{Conclusion}

For effective and efficient government expenditure, a standard performance-based budgeting must be introduced in all sectors of public expenditure and it has to be reviewed and refined from time to time. The results of government expenditures must be properly evaluated in order to enhance the output and in case of a failure, departments of government expenditure and other public bodies must re-evaluate the previously implemented methods so that the surplus in the public expenditure can be increased in an efficient manner. It is advised to the underwhelming countries that rather than focusing on allocating procedures of public expenditure, the priority should be on human development which would eventually lead to the economic growth of every individual country. Unnecessary public expenditure must be reduced and researchers should be encouraged to study the research methods that can help in proper allocation of public expenditure.

\section{REFERENCES}

[1] Moreno-Dodson, Blanca, 2008, "Assessing the Impact of Public Spending on Growth: An Empirical Analysis for seven fast Growing Countries," World Bank Policy Research Working Paper No. 4663.

[2] Barro, Robert J., and Xavier Sala-i-Martin. 1992. Convergence. Journal of Political Economy 100(2): 223-251. Published Version doi: 10.1086/261816.

[3] Blankenau and Simpson (2004) Journal of Development Economics, 2004, vol. 73, issue 2, 583605

[4] Harriss, C. L. (1954), Government Expenditure: Significant Issues of Definition. The Journal of Finance, 9: 351-364.

[5] Levine, Ross and David Renelt, 1992, A Sensitivity Analysis of Cross-Country Growth Regressions, American Economic Review, vol. 82, no. 4, 942-63.

[6] Keith Griffin and Terry McKinley December 1992, Towards a Human Development Strategy, pg.29 [Online] Available : (http://dx.doi.org/10.2139/ssrn.2273858 )

[7] https://tradingeconomics.com/united-arab-emirates/government-spending

Citation: Mohammed Reda, Mestareehih. "Expenditure Challenges in Underwhelming Countries with Special Reference To UAE." International Journal of Humanities Social Sciences and Education (IJHSSE), vol 4, no. 8, 2017, pp. 30-32. doi://dx.doi.org/10.20431/2349-0381.0408004.

Copyright: () 2017 Authors. This is an open-access article distributed under the terms of the Creative Commons Attribution License, which permits unrestricted use, distribution, and reproduction in any medium, provided the original author and source are credited. 